\title{
Volume measurements of Mittivakkat Gletscher, southeast Greenland
}

\author{
Jacob C. YDE, ${ }^{1}$ Mette Kusk GILLESPIE, ${ }^{1 *}$ Ronny LØLAND, ${ }^{1}$ Henry RUUD, ${ }^{1}$ \\ Sebastian H. MERNILD, ${ }^{2,3}$ Simon DE VILLIERS, ${ }^{1}$ N. Tvis KNUDSEN, ${ }^{4}$ \\ Jeppe K. MALMROS ${ }^{2,5}$ \\ ${ }^{1}$ Sogn og Fjordane University College, Sogndal, Norway \\ E-mail: Jacob.Yde@hisf.no \\ ${ }^{2}$ Glaciology and Climate Change Laboratory, Center for Scientific Studies/Centro de Estudios Científicos (CECs), \\ Valdivia, Chile \\ ${ }^{3}$ Climate, Ocean, and Sea Ice Modeling Group, Computational Physics and Methods, Los Alamos National Laboratory, \\ Los Alamos, NM, USA \\ ${ }^{4}$ Department of Geoscience, University of Aarhus, Aarhus, Denmark \\ ${ }^{5}$ Department of Geosciences and Natural Resource Management, University of Copenhagen, Copenhagen, Denmark
}

\begin{abstract}
Here we present ground-penetrating radar measurements of Mittivakkat Gletscher, southeast Greenland, to estimate an empirical volume-area scaling relationship at an individual glacier. Between a previous direct volume survey in 1994 and one in 2012, the glacier volume has decreased from $2.02 \mathrm{~km}^{3}$ to $1.44 \mathrm{~km}^{3}$ while the study area has decreased from $17.6 \mathrm{~km}^{2}$ to $15.8 \mathrm{~km}^{2}$. These results are in accordance with the cumulative mass loss observed by long-term mass-balance measurements (1995/96-2011/12) at Mittivakkat Gletscher and confirm that the glacier is in severe climatic disequilibrium (AAR $=0.17$ ). The observed scaling exponent $\gamma=3.14$ and coefficient $c=0.00025 \mathbf{~ k m}^{3-2 \gamma}$ are outside the range of global scaling parameters but sensitive to small uncertainties. Nevertheless, existing global volume-area scaling relationships estimate the volume of Mittivakkat Gletscher within $31 \%$ and $15 \%$ of the measured 1994 and 2011 volumes, respectively.
\end{abstract}

KEYWORDS: climate change, glacier fluctuations, glacier mapping, ground-penetrating radar

\section{INTRODUCTION}

Volume measurements of individual glaciers are crucial for projections of the contribution of glaciers and ice caps (henceforth termed 'glaciers'; excludes ice sheets) to future sea-level change because volume data are used to develop empirical volume-area scaling relationships (Chen and Ohmura, 1990; Van de Wal and Wild, 2001; Bahr and others, 2009; Radić and Hock, 2011; Bahr and Radić, 2012; Huss and Farinotti, 2012; Marzeion and others, 2012; Slangen and others, 2012; Mernild and others, 2013a; Radić and others, 2014). While glacier area $A$ is easily derived by remote sensing and is available in glacier inventories, direct measurements of glacier volumes $V$ have only been performed on a very limited number of glaciers (e.g. Cogley, 2012). This makes glacier volume the limiting variable in calibrating the power law exponent $\gamma$ and coefficient $c$ in volume-area scaling relationships (e.g. Erasov, 1968; Zhuravlev, 1988; Chen and Ohmura, 1990; Bahr and others, 1997):

$$
V=c A^{\gamma}
$$

For example, Grinsted (2013) applied an updated version of a glacier volume database compiled by Cogley (2012) containing 220 glaciers and 34 ice caps to upscale the areas of $\sim 170000$ glaciers, primarily compiled from the Randolph Glacier Inventory version 2.0 (RGl; Arendt and others, 2012), to estimate the global glacier volume to $0.35 \pm 0.07 \mathrm{~m}$ sealevel equivalent (s.l.e.). Compared to previous estimates, Grinsted (2013) refined the scaling relationship by including continentality and glacier elevation range. Other scaling methods include volume-length (Oerlemans and others, 2007; Leclercq and others, 2012) and volume-area-length relations (Radić and others, 2008; Radić and Hock, 2011). Radić and others (2014) adopted RGI and a volume-area scaling law with $c$ and $\gamma$ derived from Chen and Ohmura (1990) and Bahr (1997) to estimate a global glacier volume of $0.52 \mathrm{~m}$ s.l.e. The discrepancy between the estimates of Radić and others (2014) and Grinsted (2013) is likely to be caused by differences in the values of the scaling parameters $c$ and $\gamma$ used. This is important because volume-area scaling is a nonlinear relation. For instance, Slangen and Van de Wal (2011) found that even small variations in the scaling parameters cause significant variations in glacier volume estimations. These biases become even more pronounced when glaciers' dynamic disequilibrium with the current climate is considered (Adhikary and Marshall, 2012). There is therefore a pressing need to better elucidate the variability of the scaling parameters by obtaining more field measurements of glacier volume (e.g. Navarro and others, 2009; Martín-Español and others, 2013).

Global scaling between glacier volume and area is based on theoretical steady-state considerations (shallow-ice approximation) of typical glacier geometry, ice rheology and mass-balance gradient (Bahr and others, 1997) and empirical data (e.g. Chen and Ohmura, 1990). However, the volume-area relationships for individual glaciers are likely to deviate significantly from a global average because glacier hypsometry, ice dynamics, climate and climatic sensitivity depend on local conditions. The range of deviation has not been quantified, but Meier and others (2007)

*Formerly Mette Riger-Kusk. 
are often referenced for suggesting that for individual glaciers the magnitude of uncertainty might be $\sim 50 \%$. As an example, advancing glaciers are likely to have a different volume-area relation than receding glaciers because increase in mass balance results in a proportionally higher increase in volume than in area (e.g. Adhikary and Marshall, 2012), assuming that the advance is caused by climate change rather than dynamic instabilities (e.g. glacier surging). In the case of glacier surging, the area will increase significantly as the glacier advances, while volume is likely to decrease as part of the ice mass is relocated to lower and warmer elevations. Similarly, climate conditions and changes may cause biases as they vary widely on a global scale, but may affect glaciers in a similar way on local and regional scales. Taking these effects into consideration is important because almost all glaciers are in disequilibrium with their local climate (Stocker and others, 2013). Adhikary and Marshall (2012) have addressed this issue of glacier transition in relation to volume-area scaling and found that the widely used exponent parameter $\gamma=1.375$ (Bahr and others, 1997) is in agreement with the empirical parameter $\gamma=1.357$ (Chen and Ohmura, 1990) partly due to a coincidental offsetting of biases resulting from assuming climatic steady-state conditions (i.e. more volume) and systematic underestimation of modeled ice thicknesses (i.e. less volume). By constructing a synthetic dataset and running numerical Stokes model simulations, Adhikary and Marshall (2012) estimate that glaciers exposed to 100 years of sustained recession have a mean $\gamma$ of 1.38, which is close to $\gamma=1.375$ (Bahr and others, 1997). For glaciers, most studies have used scaling laws with $\gamma$ between 1.12 and 1.5 (summarized by Grinsted, 2013). For ice caps a lower $\gamma$ value of 1.22-1.26 has been applied, as their geometry and ice dynamics may differ from those of valley and cirque glaciers (Grinsted, 2013; Mernild and others, 2013b).

By assuming that the scaling relationship is valid worldwide, regional volume estimates have been obtained from glacier inventories (Radić and Hock, 2010; Marzeion and others, 2012; Grinsted, 2013). However, it is likely that local factors (e.g. the effects of climatic disequilibrium, glacier surge activity, differences in mass-balance gradient, and topography) may hamper the accuracy and precision of regional-scale volume estimates (Harrison, 2013). For instance, the updated Cogley (2012) database contains no direct volume measurements from Greenlandic glaciers, despite the fact that the glaciers peripheral to the Greenland ice sheet cover $\sim 130000 \pm 4000 \mathrm{~km}^{2}$ (Rastner and others, 2012 ), or $\sim 17 \%$ of the total area of glaciers (updated from $\mathrm{RGI})$. If regional or local conditions are biased (e.g. in Greenland or parts of Greenland), then regional volume estimates might be inaccurate and in need of revision.

In this paper, we present a 2012 volume measurement of Mittivakkat Gletscher, southeast Greenland. Based on a previous volume measurement from 1994 (Knudsen and Hasholt, 1999), we discuss the potential for applying the glacier's mass-balance record to validate volume change, its volume change in recent decades and its volume-area scaling parameter relationship. To our knowledge this is the first study that compares direct volume measurements on an individual glacier in order to analyze its volume-area scaling relation. The presented data also add to the limited number of glaciers with contemporary volume measurements and are valuable to better assess the contribution of Greenlandic glaciers to sea-level change, particularly when more direct volume measurements become available in the future.

\section{STUDY AREA}

Mittivakkat Gletscher $\left(65^{\circ} 42^{\prime} \mathrm{N}, 37^{\circ} 48^{\prime} \mathrm{W}\right)$ is located on Ammassalik Island (Fig. 1). The glacier is $5.5 \mathrm{~km}$ long and has an elevation range of $160-880 \mathrm{~m}$ a.s.l. (Mernild and others, 2013c). It has undergone continuous recession since the end of the Little Ice Age (Fristrup, 1970; Knudsen and others, 2008; Mernild and others, 2011). Another sign of regional warming temperature is that the equilibrium-line altitude (ELA) has moved from $\sim 500$ ma.s.l. (1996) to $730 \mathrm{~m}$ a.s.l. (average for 1996-2010) (Mernild and others, 2011), emphasizing that the glacier dynamics of Mittivakkat Gletscher are in disequilibrium with the present climate (Mernild and others, 2013d) in accordance with observations of glacier fluctuations in other regions in Greenland (Yde and Knudsen, 2007; Bjørk and others, 2012; Kargel and others, 2012; Leclercq and others, 2012). At present, the observed mean annual air temperature at $515 \mathrm{~m}$ a.s.l. is $-2.2^{\circ} \mathrm{C}(1993-$ 2011; updated from Mernild and others, 2008), and the mean annual precipitation ranges from 1400 to $1800 \mathrm{~mm}$ w.e. $\mathrm{a}^{-1}$ (1998-2006; Mernild and others, 2008).

Mittivakkat Gletscher is one of Greenland's most intensively studied glaciers, and is therefore an attractive site to conduct field-based studies with possibilities for independent validation of results. In relation to this study, two existing investigations are of interest: (1) annual net mass balance has been measured since 1995/96 (Knudsen and Hasholt, 2008; Mernild and others, 2013c); and (2) a previous study of glacier volume was conducted in 1994 (Knudsen and Hasholt, 1999). These studies provide a basis for examining recent volume change. Knudsen and Hasholt (1999) also indicate that the glacier has a temperate basal regime, which is consistent with an observed lack of basal ice facies along the present glacier margin, indicating that basal melting is higher than basal refreezing of meltwater.

The geology consists of Precambrian metamorphic gneisses with sporadic Tertiary igneous intrusions. Areas exposed by glacier recession generally lack an unconsolidated subglacial sediment layer, although patches of preserved and dated vegetation and peat have been observed at several recently exposed locations (Knudsen and others, 2008).

\section{METHODOLOGY}

Ground-penetrating radar (GPR) surveying is a well-established method for determining ice thicknesses along glacier surface profiles, which can subsequently be processed to give an estimation of glacier volume (e.g. Binder and others, 2009; Fischer, 2009; Bælum and Benn, 2011; Saintenoy and others, 2013). During the period 11-18 August 2012, one longitudinal and several transverse and marginal profiles were recorded on Mittivakkat Gletscher (Fig. 1). The separation between the transverse profiles was set to $\sim 250 \mathrm{~m}$, but areas with heavy crevassing and large supraglacial streams caused some deviation from this surveying strategy. In particular, the southern part of the study area had steepened and become more crevassed since the previous GPR survey in 1994, making it impossible to access in 2012 (Fig. 1). 


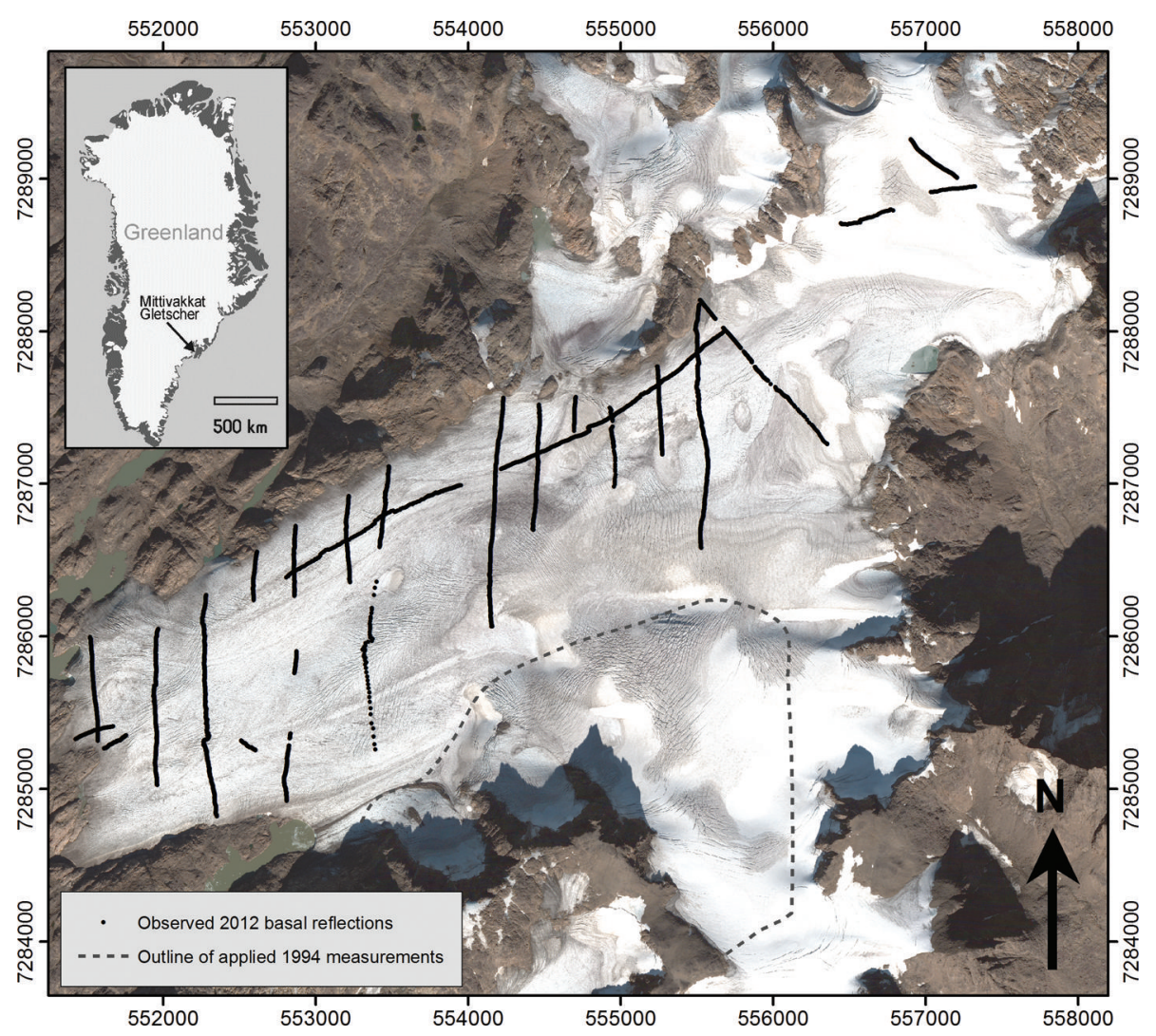

Fig. 1. Location map and QuickBird imagery (12 September 2005) of Mittivakkat Gletscher, southeast Greenland. The positions of interpretable basal reflections are marked by black dots, and the southeastern area, where the 1994 bed topography is applied, is outlined. Coordinates are given in UTM 24W (WGS 84).

The applied equipment was a MALÅ GeoScience $50 \mathrm{MHz}$ Rough Terrain Antenna attached to a MALÅ ProEx GPR system carried in a backpack (MALÅ GeoScience, 2011). During measurements the antenna was dragged inline along the profile while recording at a 1 trace $^{-1}$ sampling interval. To keep a constant spacing of $4.0 \mathrm{~m}$ between the $50 \mathrm{MHz}$ transmitter and receiver antennas, a person walked behind holding a rope attached to the end of the antenna. The radar propagation velocity was set to $0.168 \mathrm{~m} \mathrm{~ns}^{-1}$ in order to allow a direct comparison with the previous study by Knudsen and Hasholt (1999). This assumed homogeneous velocity is similar to those applied in other studies (e.g. Saetrang and Wold, $1986\left(0.169 \mathrm{~m} \mathrm{~ns}^{-1}\right)$; Melvold and Schuler, $\left.2008\left(0.168 \mathrm{~m} \mathrm{~ns}^{-1}\right)\right)$. However, considering that Mittivakkat Gletscher primarily consists of temperate ice with water present between ice crystals, it is likely that $0.168 \mathrm{~m} \mathrm{~ns}^{-1}$ is higher than actual propagation velocities (e.g. Bradford and Harper, 2005; Bradford and others, 2009). No correction for propagation velocities in snow cover was needed as the ELA was above $880 \mathrm{~m}$ in 2012 (Mernild and others, 2013c). Also, the general lack of both debris-rich basal ice and unconsolidated subglacial sediments in areas recently exposed by glacier retreat indicates that a marked contrast in propagation velocities can be expected at the ice/ bed interface.

A MALÅ single-frequency GPS was coupled to the GPR system to continuously record the positions of each GPR measurement. The uncertainty of the GPS was checked against a geodetic control point in front of the glacier and showed a vertical deviation less than $1 \mathrm{~m}$, although the potential vertical uncertainty may be up to $\pm 5-10 \mathrm{~m}$ according to the manufacturer. The glacier surface elevation was extracted from the Advanced Spaceborne Thermal Emission and Reflection Radiometer global digital elevation model version 2 (ASTER GDEM v2), a product of NASA and the Japan Ministry of Economy, Trade and Industry (METI). The elevation of the ASTER GDEM v2 is a stacked and averaged product of best observations obtained between 1999 and 2010 (Tachikawa and others, 2011). The vertical error of the ASTER GDEM v2 was $\pm 5.8 \mathrm{~m}$ when compared with in situ GPS measurements. The horizontal error between ASTER GDEM v2 and Landsat 7 Enhanced Thematic Mapper Plus (ETM+) from measurements of 26 known points outside the glacier area in both datasets was found to be $\pm 17 \mathrm{~m}$ root-mean-square error; a little more than half the pixel size. In order to provide the most accurate representation of the 2012 glacier surface topography, an interpolation of the difference between the ASTER GDEM v2 and the GPS measurements was used to correct the digital elevation model (DEM). The resulting surface topography was subsequently smoothed to remove remaining ASTER GDEM v2 artifacts.

A planimetric area of $15.9 \mathrm{~km}^{2}$ was produced in ArcGIS (Environmental Systems Research Institute (ESRI)) from a georeferenced Landsat 7 ETM+ image from 14 August 2011 (Mernild and others, 2013c). Between August 2011 and August 2012 a glacier terminus retreat of $9 \mathrm{~m}$ was measured in the field, indicating that the glacier area decreased and an adjustment is required to estimate the 2012 area. We therefore assume that the trend in area loss between 1994 (Knudsen and Hasholt, 1999) and 2011 can be linearly projected to 2012, providing an estimated 2012 area of $15.8 \mathrm{~km}^{2}$. The error of area estimation is assessed to be within $\pm 0.1 \mathrm{~km}^{2}$. 


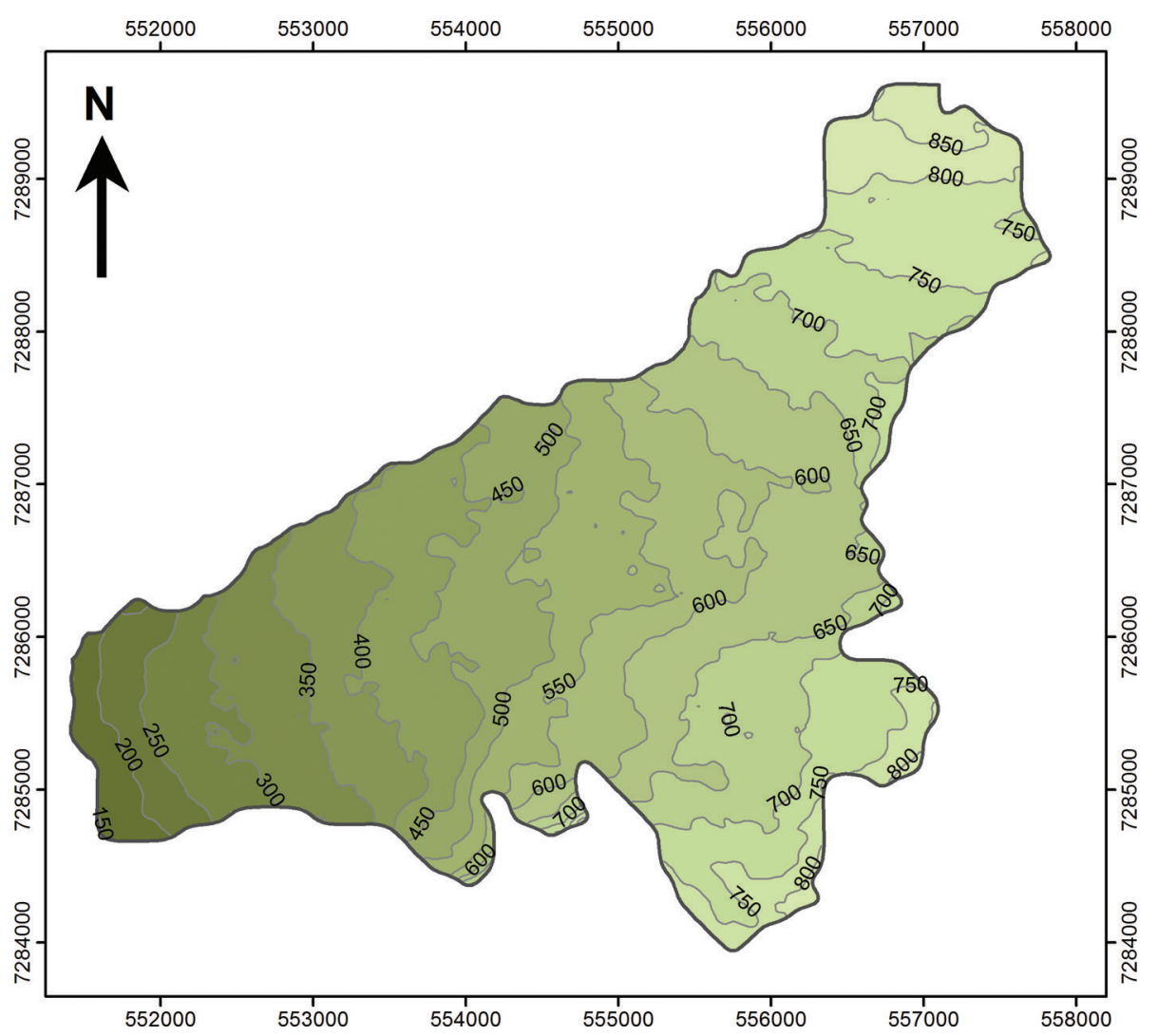

Fig. 2. Glacier surface contour map of Mittivakkat Gletscher derived from a digital elevation model based on ASTER GDEM v2 (2011). The contour interval is $50 \mathrm{~m}$.

The processing software package RadExplorer 1.42 (MALÅ GeoScience) was used to apply direct current (d.c.) removal, time adjustment, automatic gain control, bandpass filtering and Stolt F-K (frequency-wavenumber) migration (cross-profiles only) to the raw data. Bottom reflectors were observed in 23 out of 32 profiles (profiles with bottom reflectors are shown in Fig. 1). As the southeastern part of the glacier was inaccessible in 2012 due to crevasses, ice thickness in this area was calculated by subtracting the 1994 bed topography (Knudsen and Hasholt, 1999) from the 2012 DEM. The resulting ice thickness data were exported to the visualization tool ArcMap 10.1 (ESRI). Interpolation by radial basis functions was used to construct a contour map of the ice thickness, and the bed topography was calculated by subtracting the ice thickness interpolation from the DEM. The uncertainty in the measured ice thickness is often difficult to assess (e.g. Fischer, 2009), but it seems reasonable to assume that it is $~ 5 \%$ (Knudsen and Hasholt, 1999; Fischer, 2009; Bælum and Benn, 2011) where a strong basal reflection is observed. Due to the use of a relatively highfrequency $50 \mathrm{MHz}$ antenna combined with high water content within the glacier, the basal reflection was occasionally weak, so the uncertainty is likely to exceed $5 \%$ in the thickest parts of the glacier. At profile intersections, which are predominantly located in areas with relatively thick ice, the observed differences in ice thickness were generally $<10 \mathrm{~m}(\sim 10 \%$ of the total ice thickness). The uncertainty of the final ice thickness interpolation increases in areas where no measurements of ice thickness or bedrock topography exist. Finally, multiplying the mean ice thickness and the glacier area derived the glacier volume. The combined uncertainty in glacier volume arising from errors in ice thickness, propagation velocity, interpolation and glacier area is estimated to be on average $10 \%$, which is similar to that observed in comparable studies (e.g. Saintenoy and others, 2013).

\section{RESULTS}

\section{Glacier surface and basal topography}

The generated glacier surface contour map shows a surface topography that is consistent with glacier surface observations and the locations of crevasse patterns (Fig. 2) and has a mean surface slope of $5.9^{\circ}$ (Mernild and others, 2013d). Transverse crevasses are generally situated in areas with expansion below steeper compressed parts of the glacier (e.g. between 310 and $350 \mathrm{~m}$ and in the central part of the glacier between 570 and $630 \mathrm{~m}$ ). Assuming a present mean ELA at $730 \mathrm{~m}$ (Mernild and others, 2011), the mean accumulation area only constitutes $17 \%$ of the total study area. This is far less than glaciers in climatic equilibrium, which typically have accumulation areas comprising 50$60 \%$ (Dyurgerov and others, 2009), suggesting that the glacier is severely out of equilibrium with the local climate (Mernild and others, 2011, 2013c).

The glacier bed topography has an undulating appearance, with bedrock knobs and depressions (Fig. 3), similar to the topography surrounding the glacier to the north and west. A notable feature is a $3.5 \mathrm{~km}$ long subglacial ridge oriented parallel with the ice-flow direction between 300 and $600 \mathrm{~m}$ a.s.l. in the central and northern part of the glacier. This ridge was first revealed in the basal glacier topography by Knudsen and Hasholt (1999) and is likely to cause the glacier to split into a northern and southern branch if the current trend in glacier recession and thinning continues. 


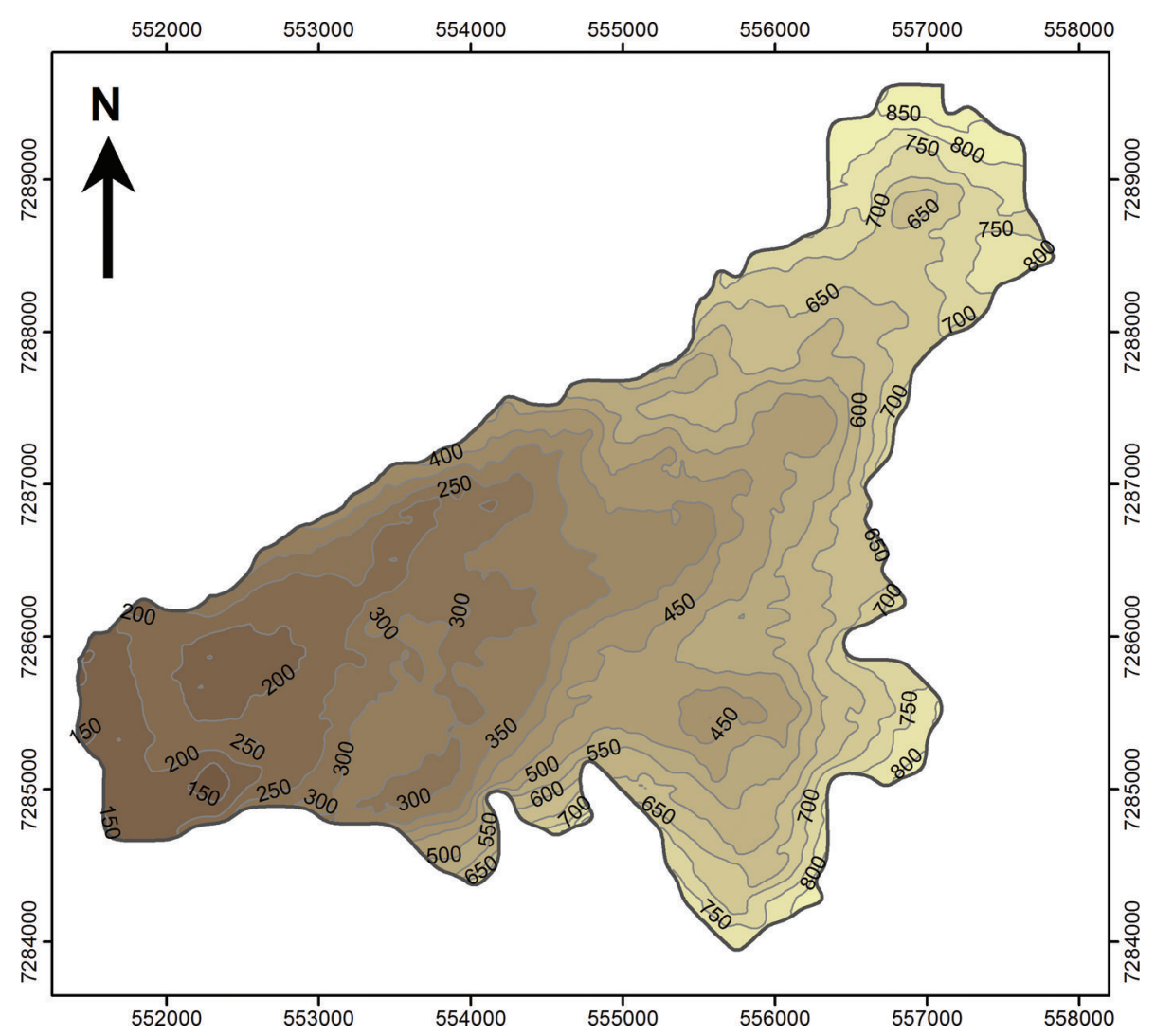

Fig. 3. Bed topography contour map of Mittivakkat Gletscher. The data for the southern part of the glacier are derived from Knudsen and Hasholt (1999). The contour interval is $50 \mathrm{~m}$.

There is a good match between bedrock morphology shown in the new bed topography contour map and the map constructed by Knudsen and Hasholt (1999). The observed correlation between the bed topography maps provides confidence in the accuracy of the 1994 GPR instrumentation and processing and implies that no significant biases will be introduced with its use in the present study to describe the now inaccessible southern part of the glacier.

\section{Ice thickness and volume}

The ice thickness rapidly increases away from the lateral glacier margins, but near the terminus and in the upper northeastern part of the glacier the marginal ice is thin and has thicknesses of $<20 \mathrm{~m}$ (Fig. 4). This is consistent with measurements of low ice velocities in these areas (Mernild and others, 2013d). A maximum ice thickness of $220 \mathrm{~m}$ was measured by the GPR at the deepest central valley, while an overall maximum interpolated ice thickness of $270 \mathrm{~m}$ was found in the southern cirque depression, where the 1994 bed topography was applied. This maximum ice thickness is actually higher than the maximum ice thickness of $245 \mathrm{~m}$ found at the same site in 1994, because of an increase in surface elevation. The computed interpolated mean ice thickness for 2012 was $90 \mathrm{~m}$, and the glacier volume was calculated at $1.44 \mathrm{~km}^{3}$ (Table 1).

\section{DISCUSSION}

\section{Comparison with mass-balance record}

The 2012 GPR survey allows a direct comparison with the findings from the 1994 GPR survey. Between 1994 and 2012 the glacier thinned by $\sim 25 \mathrm{~m}$ on average, at a rate of
$1.39 \mathrm{ma}^{-1}$ (Table 1). When corrected to meters water equivalent using an ice density of $917 \mathrm{~kg} \mathrm{~m}^{-3}$, this thinning rate $\left(1.27 \mathrm{~m}\right.$ w.e. $\left.\mathrm{a}^{-1}\right)$ is slightly higher than the mean annual net mass-balance loss of $1.01 \pm 0.74$ mw.e. $\mathrm{a}^{-1}$ between 1995/96 and 2011/12 (Mernild and others, 2013c). Given the uncertainties involved in both methods, the deviation in thinning rates is within an acceptable range. Mernild and others (2013d) combined the 1994 ice volume measurement with modeled (1986-95) and observed (1996-2011) massbalance estimates and adjusted the 1986-2011 area change using satellite images to calculate the annual volume changes of Mittivakkat Gletscher. Their study indicated a $15 \%$ reduction of the mean ice thickness between 1986 and 2011 , comparable to the $22 \%$ ice thinning that we find by GPR between 1994 and 2012. There was a lack of significant change in mean ice thickness between 1986 and 1995 (Mernild and others, 2013d). This may be explained by a stable local climate and a lack of extremes in air temperature (Mernild and others, 2014a), combined with more winter precipitation during this period (Mernild and others, 2014b). Since 1994 the local mean annual air temperature has increased by $0.07^{\circ} \mathrm{Ca}^{-1}\left(r^{2}=0.22\right.$; $p=0.035$; where $r^{2}$ is the square of the linear correlation coefficient and $p$ is the level of significance), while the mean annual precipitation has changed by $-26.5 \mathrm{~mm} \mathrm{a}^{-1}$ $\left(r^{2}=0.30 ; p=0.013\right)$ (data from the synoptic station in the village of Tasiilaq located $10 \mathrm{~km}$ from the glacier; Cappelen, 2013). These recent local climatic changes are the likely explanation for the observed thinning and ice loss.

\section{Volume and area change 1994-2012}

Between 1994 and 2012 the area of Mittivakkat Gletscher decreased from $17.6 \pm 0.1 \mathrm{~km}^{2}$ to $15.8 \pm 0.1 \mathrm{~km}^{2}$, and its ice 


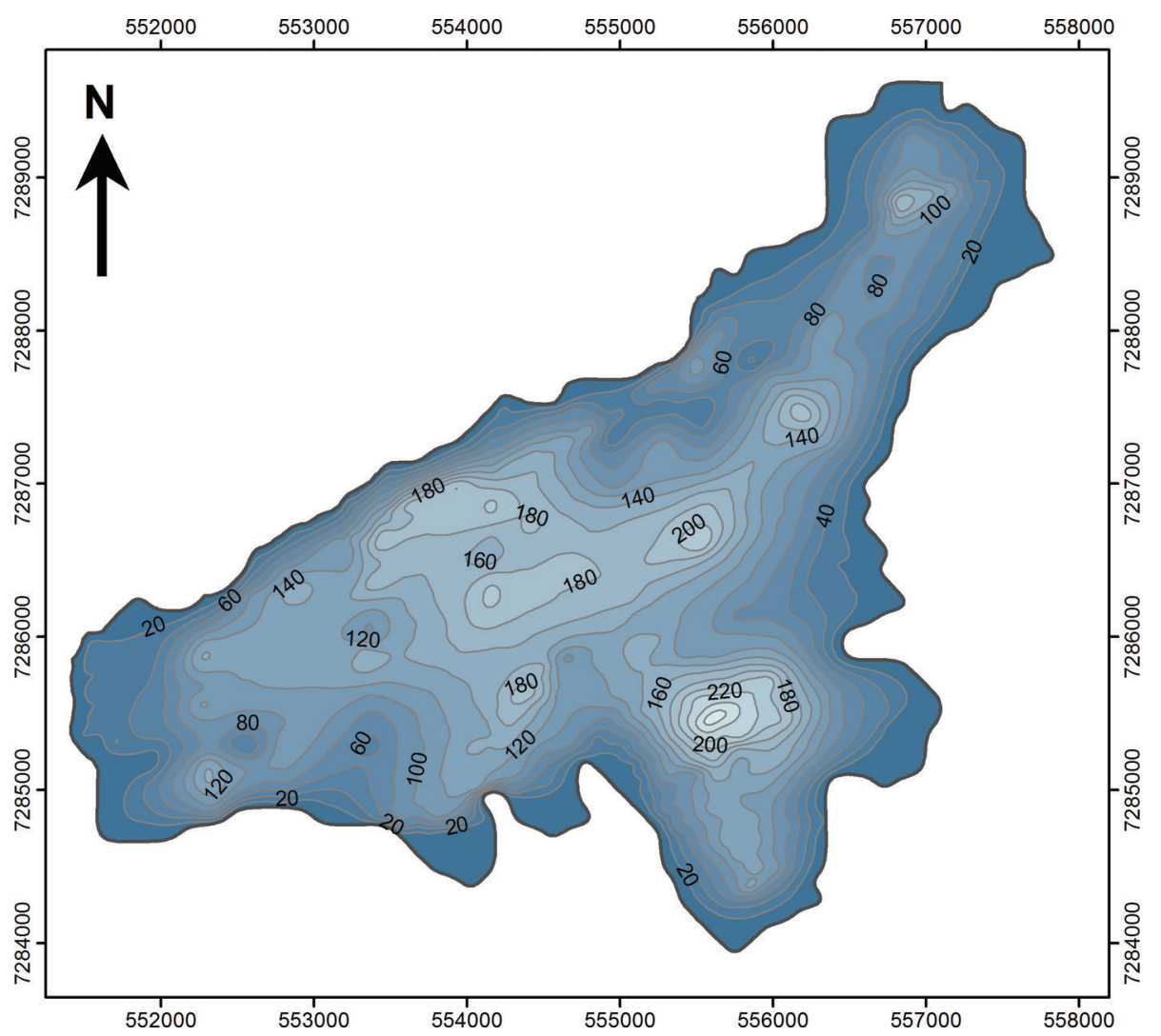

Fig. 4. Contour map of the 2012 ice thickness of Mittivakkat Gletscher. The contour interval is $20 \mathrm{~m}$.

volume decreased by $0.58 \mathrm{~km}^{3}$, equal to $29 \%$ of its 1994 volume, or $1.6 \% \mathrm{a}^{-1}$ (Table 1 ). This has resulted in recession of the glacier front by $>100 \mathrm{~m}$ between 1999 and 2010 (calculated from satellite images; Mernild and others, 2011), affecting the proglacial groundwater (Kristiansen and others, 2013) and the rate of microbial-mediated methane fluxes in exposed areas (Bárcena and others, 2010, 2011). Also, model simulations of runoff indicate that, on average, $\sim 35 \%$ of the current runoff is explained by net mass loss (Liston and Mernild, 2012).

\section{Volume-area scaling for Mittivakkat Gletscher}

Based on the two datasets of measured volume and area from 1994 and 2012, it is possible to quantify the power law coefficient $c$ and exponent $\gamma$ for Mittivakkat Gletscher using Eqn (1). This calculation shows that $\gamma=3.14$ and $c=0.00025 \mathrm{~km}^{3-2 \gamma}$. While $\gamma$ is higher than has been shown even for synthetic individual glaciers in transient states (Radić and others, 2007; Adhikary and Marshall, 2012), c is far lower than previous estimates. This association between a

Table 1. Area, mean ice thickness and volume estimates of Mittivakkat Gletscher in 2012 and 1994. The area-corrected data are from Knudsen and Hasholt (1999) and Mernild and others (2013c)

\begin{tabular}{lccc}
\hline Year & $\begin{array}{c}\text { Area } \\
\mathrm{km}^{2}\end{array}$ & $\begin{array}{c}\text { Mean ice thickness } \\
\mathrm{m}\end{array}$ & $\begin{array}{c}\text { Volume } \\
\mathrm{km}^{3}\end{array}$ \\
\hline 1994 & 17.6 & 115 & \\
2012 & 15.8 & 90 & 2.02 \\
& & & 1.44 \\
\hline
\end{tabular}

high and a low parameter is characteristic when using free parameters in power laws and partly compensates for extreme values (Adhikary and Marshall, 2012). These values of $\gamma$ and $c$ are expected to be unrealistic when projected to large changes in area and volume, but may give a better representation of the volume-area scaling of local systems far from climatic equilibrium on short timescales. It is clear that the power law parameters $\gamma$ and $c$ are sensitive to uncertainties in volume and area measurements. One way to assess this sensitivity is to determine the end-member uncertainty range by calculating minimum and maximum power law coefficients $c$ and exponents $\gamma$ from end-member uncertainties of volume and area changes. In the case of Mittivakkat Gletscher we assume volume and area change uncertainties of $10 \%$ and $\pm 0.1 \mathrm{~km}^{2}$, respectively. This sensitivity test shows that the uncertainty range of $\gamma$ is 2.05-4.34, whereas $c$ ranges between $0.0051 \mathrm{~km}^{3-2 \gamma}$ and $0.0000080 \mathrm{~km}^{3-2 \gamma}$. Here it is interesting to note that the widely used $\gamma=1.375$ (Bahr and others, 1997) falls below the uncertainty range for Mittivakkat Gletscher. This may indicate that the results for Mittivakkat Gletscher have at least two wider implications: (1) the ranges of $\gamma$ and $c$ for individual glaciers are likely to be even larger than previously expected; and (2) the consequences of glacier-specific conditions and significant climatic disequilibrium have to be understood in more detail in order to more accurately assess glacier volumes from volume-area relations on local and regional scales. However, it must be emphasized that the scaling parameters obtained serve to illustrate that there are large local deviations from the global behavior and should not be used for extrapolation in space and time.

The coefficient $c$ is considered to be poorly constrained as its unit depends on $\gamma$ (Slangen and Van de Wal, 2011). 
Therefore, it is also problematic to compare $c$ between studies if different $\gamma$ have been applied. As the geometry of Mittivakkat Gletscher resembles that of a valley glacier, it seems appropriate to compare the degree of scaling $\gamma$ at Mittivakkat Gletscher with other studies by constraining $c$ to 0.0433 , the empirical value determined by Grinsted (2013) on a set of 220 glaciers updated from Cogley (2012). This shows that the associated $\gamma$ changes from 1.34 to 1.27 between 1994 and 2012. This decrease in $\gamma$ provides empirical support for the finding of Adhikary and Marshall (2012), based on synthetic data, that sustained glacier recession causes a decreasing trend in $\gamma$. It should also be noted that the values of $\gamma$ are close to $\gamma=1.29$ as used by Grinsted (2013). This proximity is reflected in the fact that the scaling regression used by Grinsted (2013) only underestimates the 1994 volume of Mittivakkat Gletscher by $13 \%$ and overestimates the 2012 volume by $6 \%$ (Table 2). Other global scaling regressions fit Mittivakkat Gletscher less accurately. For example, the scaling regressions used by Chen and Ohmura (1990) and Adhikary and Marshall (2012) underestimate the 1994 and 2012 volumes by $31 \%$ and $15 \%$, respectively, whereas the Radic and Hock (2010) scaling regression underestimates the 1994 volume by $7 \%$ and overestimates the volume in 2012 by $14 \%$ (Table 2). Based on volume residuals, the scaling regression by Radić and Hock (2010) provides the best fit of the four scaling regressions (Table 2). These deviations highlight the considerable range of volume estimates and potential biases for an individual glacier, although it has to be remembered that uncertainties are involved in both the applied volume-area scaling equations and the underlying volume and area measurements.

\section{CONCLUSIONS}

We have provided a new volume measurement of Mittivakkat Gletscher to analyze its volume-area scaling parameter relation. The glacier is severely out of equilibrium with the local climate, and a comparison between a previous direct volume survey in 1994 and the new survey in 2012 shows that the volume of the glacier has changed from $2.02 \mathrm{~km}^{3}$ to $1.44 \mathrm{~km}^{3}$, a decrease equal to $29 \%$ of its 1994 volume. Meanwhile, the glacier area has decreased from $17.6 \mathrm{~km}^{2}$ to $15.8 \mathrm{~km}^{2}$. In 2012, the mean ice thickness was $90 \mathrm{~m}$, with a maximum ice thickness of $270 \mathrm{~m}$. The mean thinning rate between 1994 and 2012 was 1.27 m w.e. $\mathrm{a}^{-1}$. This change in ice volume provides independent validation of the mean mass change of $-1.01 \pm 0.74 \mathrm{~m}$ w.e. $\mathrm{a}^{-1}$ observed by massbalance measurements (1995/96-2011/12). The contemporary volume-area scaling exponent $\gamma=3.14$ and coefficient $c=0.00025 \mathrm{~km}^{3-2 \gamma}$ of Mittivakkat Gletscher are outside the range of global scaling parameters, which is likely due to climate disequilibrium and local glaciological conditions (e.g. glacier hypsometry and ice dynamics).

Although Mittivakkat Gletscher has been in disequilibrium with the local climate since the mid-1990s, the volume-area scaling relationships by Radić and Hock (2010) and Grinsted (2013) estimate the volume to be within $14 \%$ of the measured volume, whereas volume estimates based on the scaling relationships by Chen and Ohmura (1990) and Adhikary and Marshall (2012) are within $31 \%$. Considering the uncertainties involved in both GPR measurements and applied volume-area scaling relationships, the volume-area scaling relationships are
Table 2. The performance of global-scale power law relations in estimating the volume of Mittivakkat Gletscher in $1994\left(V_{1994}\right)$ and $2012\left(V_{2012}\right)$

\begin{tabular}{lllll}
\hline \multirow{2}{*}{ Source } & \multicolumn{1}{c}{$c$} & $\gamma$ & \multicolumn{3}{c}{ Estimated } \\
& & & $\begin{array}{c}V_{1994} \\
\mathrm{~km}^{3}\end{array}$ & $V_{2012}$ \\
& $\mathrm{~km}^{3-2 \gamma}$ & & & \\
\hline Chen and Ohmura (1990) & 0.0285 & 1.357 & 1.40 & 1.21 \\
Radić and Hock (2010) & 0.0365 & 1.375 & 1.88 & 1.62 \\
Adhikary and Marshall (2012) & 0.027 & $1.377^{*}$ & 1.40 & 1.21 \\
Grinsted (2013) & 0.0433 & 1.29 & 1.75 & 1.52 \\
\hline
\end{tabular}

*Magnitude after 100 years of sustained recession.

accurate to within the range of 50\% suggested for individual glaciers by Meier and others (2007).

\section{ACKNOWLEDGEMENTS}

This study was funded by an EC FP7 (European Commission seventh framework program) Interact grant agreement No. 262693 (project GLAMOSEG II). R.L. was supported by funding from Sogn og Fjordane University College.

\section{REFERENCES}

Adhikary S and Marshall SJ (2012) Glacier volume-area relation for high-order mechanics and transient glacier states. Geophys. Res. Lett., 39(16), L16505 (doi: 10.1029/2012GL052712)

Arendt A and 77 others (2012) Randolph Glacier Inventory (RGI), Vers. 2.0: a dataset of global glacier outlines. Global Land Ice Measurements from Space, Boulder, CO. Digital media: http:// www.glims.org/RGl/randolph.html

Bælum K and Benn DI (2011) Thermal structure and drainage system of a small valley glacier (Tellbreen, Svalbard), investigated by ground penetrating radar. Cryosphere, 5(1), 139-149 (doi: 10.5194/tc-5-139-2011)

Bahr DB (1997) Global distributions of glacier properties: a stochastic scaling paradigm. Water Resour. Res., 33(7), 1669-1679 (doi: 10.1029/97WR00824)

Bahr DB and Radić V (2012) Significant contribution to total mass from very small glaciers. Cryosphere, 6(4), 763-770 (doi: 10.5194/tc-6-763-2012)

Bahr DB, Meier MF and Peckham SD (1997) The physical basis of glacier volume-area scaling. J. Geophys. Res., 102(B9), 20355-20362 (doi: 10.1029/97JB01696)

Bahr DB, Dyurgerov M and Meier MF (2009) Sea-level rise from glaciers and ice caps: a lower bound. Geophys. Res. Lett., 36(3), L03501 (doi: 10.1029/2008GL036309)

Bárcena TG, Yde JC and Finster KW (2010) Methane flux and highaffinity methanotrophic diversity along the chronosequence of a receding glacier in Greenland. Ann. Glaciol., 51(56), 23-31 (doi: 10.3189/172756411795932001)

Bárcena TG, Finster KW and Yde JC (2011) Spatial patterns of soil development, methane oxidation, and methanotrophic diversity along a receding glacier forefield, southeast Greenland. Arct. Antarct. Alp. Res., 43(2), 178-188

Binder D, Brückl E, Roch KH, Behm M, Schöner W and Hynek B (2009) Determination of total ice volume and ice-thickness distribution of two glaciers in the Hohe Tauern region, Eastern Alps, from GPR data. Ann. Glaciol., 50(51), 71-79 (doi: 10.3189/172756409789097522)

Bjørk AA and 8 others (2012) An aerial view of 80 years of climaterelated glacier fluctuations in southeast Greenland. Nature Geosci., 5(6), 427-432 (doi: 10.1038/ngeo1481) 
Bradford JH and Harper JT (2005) Wave field migration as a tool for estimating spatially continuous radar velocity and water content in glaciers. Geophys. Res. Lett., 32(8), L08502 (doi: 10.1029/ 2004GL021770)

Bradford JH, Nichols J, Mikesell TD and Harper JT (2009) Continuous profiles of electromagnetic wave velocity and water content in glaciers: an example from Bench Glacier, Alaska, USA. Ann. Glaciol., 50(51), 1-9 (doi: 10.3189/172756409789097540)

Cappelen J (2013) Weather observations from Greenland 19582012. (Tech. Rep. 13-11) Danish Meteorological Institute, Ministry of Climate and Energy, Copenhagen

Chen J and Ohmura A (1990) Estimation of Alpine glacier water resources and their change since the 1870s. IAHS Publ. 193 (Symposium at Lausanne 1990 - Hydrology in Mountainous Regions), 127-135

Cogley JG (2012) The future of the world's glaciers. In HendersonSellers A and McGuffie K eds. The future of the world's climate. Elsevier, Waltham, MA, 197-222

Dyurgerov M, Meier MF and Bahr DB (2009) A new index of glacier area change: a tool for glacier monitoring. J. Glaciol., 55(192), 710-716 (doi: 10.3189/002214309789471030)

Erasov NV (1968) Method to determine the volume of mountain glaciers. Mater. Glyatsiol. Issled., 14, 307-308

Fischer A (2009) Calculation of glacier volume from sparse icethickness data, applied to Schaufelferner, Austria. J. Glaciol., 55(191), 453-460 (doi: 10.3189/002214309788816740)

Fristrup B (1970) Ny geografisk station i Grønland. Geogr. Tidsskr., 69, 192-203

Grinsted A (2013) An estimate of global glacier volume. Cryosphere, 7(1), 141-151 (doi: 10.5194/tc-7-141-2013)

Harrison WD (2013) How do glaciers respond to climate? Perspectives from the simplest models. J. Glaciol., 59(217), 949-960 (doi: 10.3189/2013JoG13J048)

Huss M and Farinotti D (2012) Distributed ice thickness and volume of all glaciers around the globe. J. Geophys. Res., 117(F4), F04010 (doi: 10.1029/2012JF002523)

Kargel JS and 15 others (2012) Greenland's shrinking ice cover: 'fast times' but not that fast. Cryosphere, 6(3), 533-537 (doi: 10.5194/tc-6-533-2012)

Knudsen NT and Hasholt B (1999) Radio-echo sounding at the Mittivakkat Gletscher, southeast Greenland. Arct. Antarct. Alp. Res., 31(3), 321-328

Knudsen NT and Hasholt B (2008) Mass balance observations at Mittivakkat Gletscher, Southeast Greenland 1995-2006. Geogr. Tidsskr., 108(1), 111-120

Knudsen NT, Nørnberg P, Yde JC, Hasholt B and Heinemeier J (2008) Recent marginal changes of the Mittivakkat Glacier, Southeast Greenland and the discovery of remains of reindeer (Rangifer tarandus), polar bear (Ursus maritimus) and peaty material. Geogr. Tidsskr., 108(1), 137-142

Kristiansen SM, Yde JC, Bárcena TG, Jakobsen BH, Olsen J and Knudsen NT (2013) Geochemistry of groundwater in front of a warm-based glacier in Southeast Greenland. Geogr. Ann. A, 95(2), 97-108 (doi: 10.1111/geoa.12003)

Leclercq PW, Weidick A, Paul F, Bolch T, Citterio M and Oerlemans J (2012) Historical glacier length changes in West Greenland. Cryosphere, 6(6), 1339-1343 (doi: 10.5194/tc-6-1339-2012)

Liston GE and Mernild SH (2012) Greenland freshwater runoff. Part I: a runoff routing model for glaciated and nonglaciated landscapes (HydroFlow). J. Climate, 25(17), 5997-6014 (doi: 10.1175/JCLI-D-11-00591.1)

MALÅ GeoScience (2011) MALÅ ProEx Control Unit Manual v.2.o. MALÅ GeoScience, Malå.

Martín-Español A and 7 others (2013) Radio-echo sounding and ice volume estimates of western Nordenskiöld Land glaciers, Svalbard. Ann. Glaciol., 54(64), 211-217 (doi: 10.3189/ 2013AoG64A109)

Marzeion B, Jarosch AH and Hofer M (2012) Past and future sealevel change from the surface mass balance of glaciers. Cryosphere, 6(6), 1295-1322 (doi: 10.5194/tc-6-1295-2012)
Meier MF and 7 others (2007) Glaciers dominate eustatic sea-level rise in the 21st century. Science, 317(5841), 1064-1067 (doi: 10.1126/science.1143906)

Melvold K and Schuler TV (2008) Mapping of subglacial topography using GPR for determining subglacial hydraulic conditions. In Hauck C and Kneisel C eds. Applied geophysics in periglacial environments. Cambridge University Press, Cambridge, 191-206

Mernild SH, Hansen BU, Jakobsen BH and Hasholt B (2008) Climatic conditions at the Mittivakkat Glacier catchment (19942006), Ammassalik Island, SE Greenland, and in a 109-year perspective (1898-2006). Geogr. Tidsskr., 108(1), 51-72

Mernild SH and 6 others (2011) Increasing mass loss from Greenland's Mittivakkat Gletscher. Cryosphere, 5(2), 341-348 (doi: 10.5194/tc-5-341-2011)

Mernild SH, Yde JC, Malmros JK and Knudsen NT (2013a) Landterminating glacier volume changes in different Circum-Arctic areas, mid-1980s to late-2000s/2011. Geogr. Tidsskr., 113(1), 65-70 (doi: 10.1080/00167223.2013.799311)

Mernild SH, Lipscomb WH, Bahr DB, Radić $V$ and Zemp M (2013b) Global glacier changes: a revised assessment of committed mass losses and sampling uncertainties. Cryosphere, 7(5), 1565-1577 (doi: 10.5194/tc-7-1565-2013)

Mernild SH, Pelto M, Malmros JK, Yde JC, Knudsen NT and Hanna E (2013c) Identification of snow ablation rate, ELA, AAR, and net mass balance using transient snowline variations on two Arctic glaciers. J. Glaciol., 59(216), 649-659 (doi: 10.3189/ 2013JoG12J221)

Mernild SH and 7 others (2013d) Volume and velocity changes at Mittivakkat Gletscher, southeast Greenland. J. Glaciol., 59(216), 660-670 (doi: 10.3189/2013JoG13J017)

Mernild SH, Hanna E, Yde JC, Cappelen J and Malmros JK (2014a) Coastal Greenland air temperature extremes and trends 18902010: annual and monthly analysis. Int. J. Climatol., 34(5), 1472-1487 (doi: 10.1002/joc.3777)

Mernild SH and 9 others (2014b) Greenland precipitation trends in a long-term instrumental climate context (1890-2012): evaluation of coastal and ice core records. Int. J. Climatol., 34 (doi: 10.1002/joc.3986)

Navarro FJ and 6 others (2009) Radioglaciological studies on Hurd Peninsula glaciers, Livingston Island, Antarctica. Ann. Glaciol., 50(51), 17-24 (doi: 10.3189/172756409789097603)

Oerlemans J, Dyurgerov M and Van de Wal RSW (2007) Reconstructing the glacier contribution to sea-level rise back to 1850 . Cryosphere, $\mathbf{1}(1), 59-65$

Radić V and Hock R (2010) Regional and global volumes of glaciers derived from statistical upscaling of glacier inventory data. J. Geophys. Res., 115(F1), F01010 (doi: 10.1029/ 2009JF001373)

Radić V and Hock R (2011) Regionally differentiated contribution of mountain glaciers and ice caps to future sea-level rise. Nature Geosci., 4(2), 91-94 (doi: 10.1038/ngeo1052)

Radić V, Hock R and Oerlemans J (2007) Volume-area scaling vs flowline modelling in glacier volume projections. Ann. Glaciol., 46, 234-240 (doi: 10.3189/172756407782871288)

Radić V, Hock R and Oerlemans J (2008) Analysis of scaling methods in deriving future volume evolutions of valley glaciers. J. Glaciol., 54(187), 601-612 (doi: 10.3189/002214308786570809)

Radić V, Bliss A, Beedlow AC, Hock R, Miles E and Cogley JG (2014) Regional and global projections of twenty-first century glacier mass changes in response to climate scenarios from global climate models. Climate Dyn., 42(1-2), 37-58 (doi: 10.1007/s00382-013-1719-7)

Rastner P, Bolch T, Mölg N, Machguth H, Le Bris R and Paul F (2012) The first complete inventory of the local glaciers and ice caps on Greenland. Cryosphere, 6(6), 1483-1495 (doi: 10.5194/tc-6-1483-2012)

Saetrang AC and Wold B (1986) Results from the radio echosounding on parts of the Jostedalsbreen ice cap, Norway. Ann. Glaciol., 8, 156-158 
Saintenoy A and 7 others (2013) Deriving ice thickness, glacier volume and bedrock morphology of Austre Lovénbreen (Svalbard) using GPR. Near Surf. Geophys., 11(2), 253-261 (doi: 10.3997/1873-0604.2012040)

Slangen ABA and Van de Wal RSW (2011) An assessment of uncertainties in using volume-area modelling for computing the twenty-first century glacier contribution to sea-level change. Cryosphere, 5(3), 673-686 (doi: 10.5194/tc-5-673-2011)

Slangen ABA, Katsman CA, Van de Wal RSW, Vermeersen LLA and Riva REM (2012) Towards regional projections of twenty-first century sea-level change based on IPCC SRES scenarios. Climate Dyn., 38(5-6), 1191-1209 (doi: 10.1007/s00382-011-1057-6)

Stocker TF and 9 others eds. (2013) Climate change 2013: the physical science basis. Contribution of Working Group I to the Fifth Assessment Report of the Intergovernmental Panel on Climate Change. Cambridge University Press, Cambridge and New York
Tachikawa T and 12 others (2011) ASTER Global Digital Elevation Model Version 2 - summary of validation results. NASA Land Processes Distributed Active Archive Center/Joint Japan-US ASTER Science Team http://www.jspacesystems.or.jp/ersdac/ GDEM/ver2Validation/Summary_GDEM2_validation_report_ final.pdf

Van de Wal RSW and Wild M (2001) Modelling the response of glaciers to climate change by applying volume-area scaling in combination with a high resolution GCM. Climate Dyn., 18(3-4), 359-366 (doi: 10.1007/s003820100184)

Yde JC and Knudsen NT (2007) 20th-century glacier fluctuations on Disko Island (Qeqertarsuaq), Greenland. Ann. Glaciol., 46, 209-214 (doi: 10.3189/172756407782871558)

Zhuravlev AV (1988) The relation between glacier area and volume. In Avsyuk GA ed. Data of glaciological studies: chronicle discussions, volume 40. (Russian Translations Series 67) AA Balkema, Rotterdam, 441-446

MS received 6 March 2014 and accepted in revised form 2 August 2014 